\title{
Anterior Segment Optical Coherence Tomography in the Early Management of Microbial Keratitis: A Cross- -Sectional Study
}

\section{Tomografia de Coerência Ótica na Orientação Precoce das Queratites Infeciosas: Um Estudo Transversal}

\author{
Mariana Almeida OLIVEIRA $\rrbracket^{1}$, Andreia ROSA ${ }^{1,2}$, Mário SOARES ${ }^{1}$, João GIL ${ }^{1,2}$, Esmeralda $\operatorname{COSTA}^{1,2}$, \\ Maria João QUADRADO ${ }^{1,2}$, Joaquim MURTA ${ }^{1,2}$ \\ Acta Med Port 2020 May;33(5):318-325 - https://doi.org/10.20344/amp.12663
}

\section{ABSTRACT}

Introduction: Infectious keratitis is an important cause of visual loss. The purpose of this study was to investigate anterior segment optical coherence tomography patterns in infectious keratitis and evaluate the role of this tool in the early management of this disorder. Material and Methods: In this cross-sectional study, we included patients with proven infectious keratitis, either by culture or therapeutic trial. Subjects underwent baseline anterior segment optical coherence tomography (Spectralis ${ }^{\circledR}$ anterior segment module, Heidelberg Engineering, Germany) performed by the same operator. We used anterior segment optical coherence tomography vertical and horizontal raster default scans with $6.0 \mathrm{~mm}$ scan lines.

Results: Twenty-five patients (14 men and 11 women) were included. The most common risk factors identified were ocular trauma (11 cases) and contact lens wear (7 cases). Fifteen patients presented bacterial infection; three, fungal infection; two parasitic infection; and five cases presented a negative microbiological culture. Anterior segment optical coherence tomography depicted nine distinct morphological patterns.

Discussion: Anterior segment optical coherence tomography allows the depth of corneal involvement to be assessed. When the only patterns identified were hyperreflective stromal lesion and stromal edema, the visual outcome was better. Cystic spaces were present in severe bacterial keratitis.

Conclusion: Anterior segment optical coherence tomography can complement biomicroscopy, allowing for a better characterization of corneal involvement at presentation that can help in staging and providing useful prognostic information.

Keywords: Corneal Ulcer; Eye Infections, Bacterial; Keratitis; Tomography, Optical Coherence

\section{RESUMO}

Introdução: As queratites infeciosas são uma causa importante de perda da acuidade visual. O objetivo deste estudo foi investigar padrões das queratites infeciosas na tomografia de coerência ótica do segmento anterior e avaliar o seu papel na orientação precoce desta patologia.

Material e Métodos: Neste estudo transversal, incluímos doentes com queratite infeciosa comprovada, por cultura microbiológica ou prova terapêutica. Os doentes foram submetidos a tomografia de coerência ótica do segmento anterior na baseline (Spectralis ${ }^{\circledR}$ anterior segment module, Heidelberg Engineering, Germany) executados pelo mesmo operador. Adquiriram-se cortes verticais e horizontais de 6,0 mm com tomografia de coerência ótica spectral domain.

Resultados: Foram incluídos 25 doentes (14 homens e 11 mulheres). Os fatores de risco mais comummente identificados foram o trauma ocular (11 casos) e o uso de lentes de contato (sete casos). Quinze doentes apresentaram infeção bacteriana, três infeção fúngica, dois infeção parasitária e cinco casos apresentaram culturas microbiológicas negativas. Distinguiram-se nove padrões morfológicos na tomografia de coerência ótica do segmento anterior.

Discussão: A tomografia de coerência ótica do segmento anterior permite avaliar a profundidade do envolvimento corneano na queratite infeciosa. Quando os únicos padrões identificados eram a lesão estromal hiper-refletiva e edema estromal o outcome visual foi melhor. Os espaços quísticos observaram-se nas queratites bacterianas graves.

Conclusão: A tomografia de coerência ótica do segmento anterior permite complementar a biomicroscopia, melhorar o estadiamento e fornecer informação prognóstica útil nas queratites infeciosas.

Palavras-chave: Infecções Oculares Bacterianas; Queratite; Tomografia de Coerência Óptica; Úlcera da Córnea

\section{INTRODUCTION}

Infectious keratitis (IK) is an important ocular condition that can lead to severe visual disability. ${ }^{1}$ The most commonly identified predisposing factors for bacterial and fungal keratitis are contact lens wear, ocular trauma, ocular surface disease, prior ocular surgery and systemic diseases such as diabetes mellitus, arterial hypertension, rheumatoid arthritis and hypothyroidism..$^{2-5}$

Epidemiologically, the annual incidence is highly varia-

ble, and it depends on the geographic region (from 6.3:100 000 in Hong Kong and 11:100 000 in the United States, to $710: 100000$ in Burma), which may reflect the variability in exposure to risk factors. ${ }^{1}$

The main clinical sign of infectious keratitis is a corneal ulcer. In most cases, it consists of a defect in the corneal epithelium with inflammation of the underlying corneal stroma, the severity of which depends on the predisposing

1. Department of Ophthalmology. Coimbra Hospital and University Center. Coimbra. Portugal.

2. Department of Ophthalmology. Faculty of Medicine. University of Coimbra. Coimbra. Portugal.

$\triangle$ Autor correspondente: Mariana Almeida Oliveira. mariana.alg.oliveira@gmail.com

Recebido: 07 de agosto de 2019 - Aceite: 02 de outubro de 2019 | Copyright @ Ordem dos Médicos 2020 


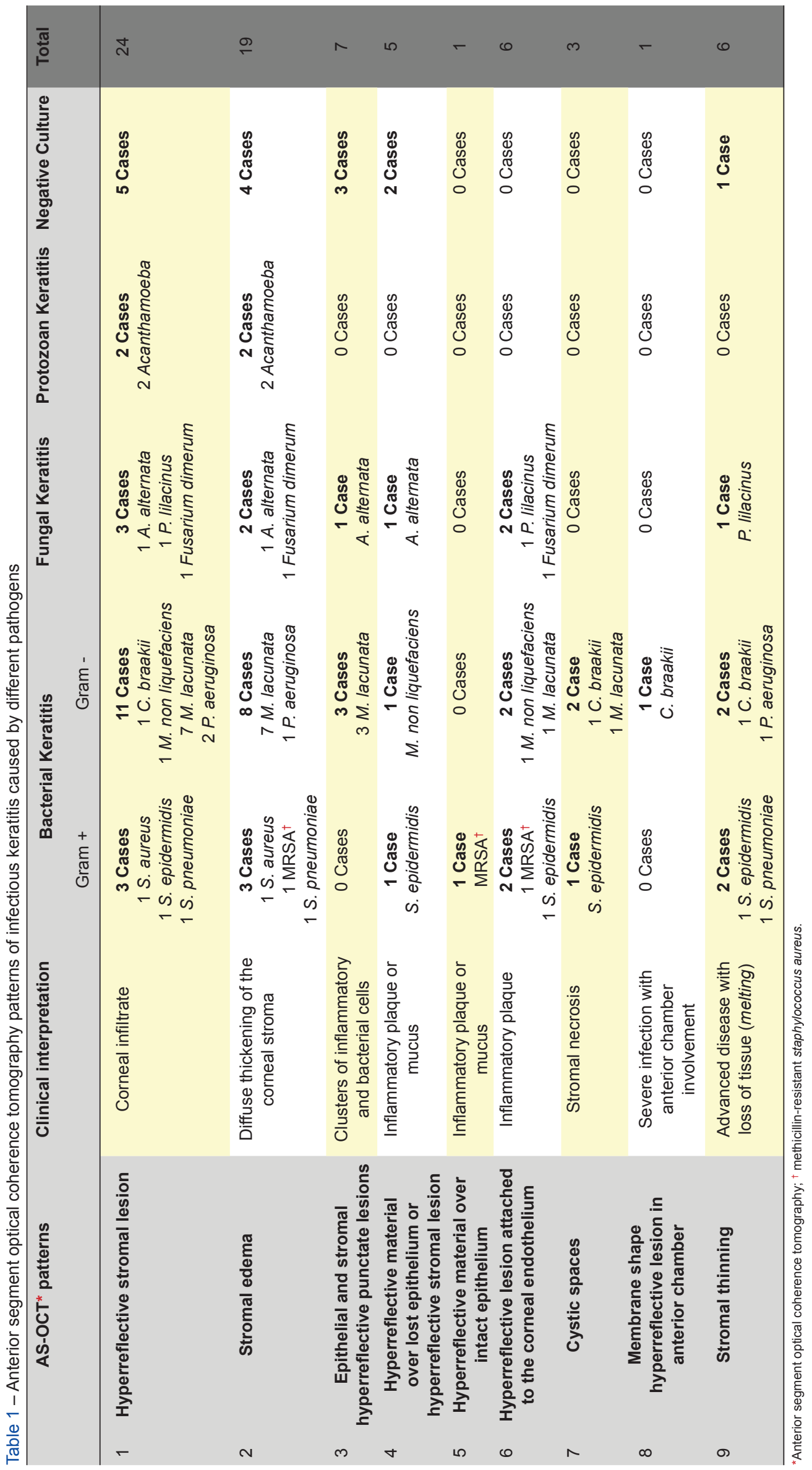


factors of the host and the causative organism. It can progress rapidly and cause severe visual impairment, thus being considered a medical emergency. ${ }^{6}$ Consequently, prompt diagnosis and initiation of an aggressive course of therapy are indispensable to limit tissue damage. Clinical diagnosis and management typically depend on slit-lamp observation. Specific treatment requires identification of the pathogens involved. Except for polymerase chain reaction (PCR), methods to identify the pathogen, namely a gram stain and culture of corneal infiltrates, are time-consuming. Microbiological tests are frequently negative due to the inadequate amount of tissue collected in corneal specimens; thus, clinical signs observed by slit-lamp biomicroscopy or other devices are relevant for making a diagnosis and choosing an appropriate empirical treatment. ${ }^{7,8}$ Slit-lamp examination allows the lesion to be located and measured vertically and horizontally; however, it does not characterize the stromal edema and is examiner-dependent. ${ }^{9}$

First described in 1994 by lzatt et al, ${ }^{10}$ anterior segment optical coherence tomography (AS-OCT) is a noncontact optical device that provides cross-sectional images of internal structures in biological tissues such as the cornea and anterior chamber. ${ }^{11}$ This technology has been used to analyze the corneal morphology in patients with several corneal conditions, such as bullous keratopathy, keratoconus and after keratoplasty, and it may have an important role in the early approach to microbial keratitis. ${ }^{11,12}$ Recent publications have suggested that AS-OCT has potential in the management of IK. ${ }^{13}$ Soliman et a/ ${ }^{14}$ described 12 morphological patterns of IK and differential corneal layer affections using AS-OCT, and clinically interpreted some of the lesions.

The purpose of this study is to investigate AS-OCT patterns in microbial keratitis, which may help determine the causative agent, and to evaluate the role of AS-OCT in the early management of this pathology.

Table 2 - Clinical findings by microbiological result

\begin{tabular}{ll}
\hline Pathogen & Major signs in slit-lamp examination \\
\hline $\begin{array}{l}\text { Moraxella non liquefaciens } \\
\text { Citrobacterbraakii }\end{array}$ & $\begin{array}{l}\text { Conjunctival injection, corneal infiltration, descemetitis, hypopyon } \\
\text { Conjunctival injection, corneal ulcer and infiltration, hypopyon }\end{array}$ \\
$\begin{array}{l}\text { P. aeruginosa } \\
\text { iris bombe }\end{array}$ & Conjunctival injection, ring-shaped corneal infiltration, hypopyon \\
S. aureus & Chemosis, penetrant keratoplasty with a corneal infiltration in the donor cornea \\
S. epidermidis & Conjunctival injection, inferior corneal ulcer and infiltration with associated thinning \\
S. pneumoniae & Conjunctival injection, penetrating keratoplasty with generalized corneal infiltration in the donor tissue \\
Alternaria alternata & Conjunctival injection, localized corneal infiltration \\
Paecilomyces lilacinus & Conjunctival injection, penetrating keratoplasty with central corneal ulcer and infiltration in the donor \\
Fusarium dimerum & cornea, hypopyon, severe anterior chamber reaction \\
Acanthamoeba & Conjunctival injection, corneal ulcer and infiltration, hypopyon \\
Negative culture & Conjunctival injection, central corneal ulcer and infiltration, hypopyon \\
\hline
\end{tabular}

\section{MATERIAL AND METHODS}

We performed a cross-sectional study of 26 consecutive patients, hospitalized in our department, with clinical suspicion of infectious keratitis, observed from January 2016 to November 2017. The study adhered to the tenets of the ics Committee. The diagnosis of infectious keratitis was confirmed by microbiological cultures (20 patients) or by a positive response to empirical treatment (5 patients). One patient was excluded as there was no follow-up and thus a lack of diagnostic confirmation.

Treatment was initiated based on clinical findings. All patients underwent imaging with Spectralis ${ }^{\circledR}$ OCT model S3300 with anterior segment module from Heidelberg Engineering, Heidelberg, Germany; 40-kHz (40 000 A-scans per second) spectral domain OCT, with a center wavelength of $870 \mathrm{~nm}$. After the anterior segment lens was placed and the patient positioned, focus location was set to $\pm 0.00 \mathrm{~mm}$. A pre-set line of an 8-mm scan was chosen from the Cornea module. Averaging of the images (ART mean) and angle variation were used to ensure noise reduction and to obtain crisp and detailed features of the abnormalities being identified. All tests were supervised by the same experienced operator in the first 48 hours after presenting to the ophthalmology department. As treatment was immediately implemented, most of the tests were performed after antibiotic treatment had commenced.

We recorded patients' demographics, clinical findings, information related to microbiological tests of corneal specimens and detection of viral DNA (performed when clinically suspected) in the cornea and aqueous humor by PCR, and treatment response.

\section{RESULTS}

Twenty-five eyes of twenty-five patients (14 men and 11 women; mean age $55.2 \pm 20.1$ ) with infectious keratitis were included. Declaration of Helsinki and was approved by the local Eth- 
Table 3 - Risk factors for infectious keratitis and its association with microbiological results

\begin{tabular}{|c|c|c|c|c|c|c|c|}
\hline Pathogen & $\begin{array}{l}\text { Ocular } \\
\text { trauma } \\
\text { (n) }\end{array}$ & $\begin{array}{l}\text { Contact } \\
\text { lenses } \\
(n)\end{array}$ & $\begin{array}{c}\text { Ocular } \\
\text { surgery } \\
(n)\end{array}$ & $\begin{array}{l}\text { Systemic } \\
\text { disease } \\
\text { (n) }\end{array}$ & $\begin{array}{l}\text { Ocular surface } \\
\text { disorder } \\
\text { (n) }\end{array}$ & $\begin{array}{l}\text { Ocular } \\
\text { corticotherapy } \\
\text { (n) }\end{array}$ & $\begin{array}{l}\text { No risk } \\
\text { actor } \\
\text { (n) }\end{array}$ \\
\hline Moraxela non liquefaciens & - & - & 1 & - & - & - & - \\
\hline Moraxela lacunata & 5 & - & - & 1 & - & - & 1 \\
\hline Citrobacter braakii & - & - & - & - & 1 & - & - \\
\hline$P$. aeruginosa & - & 1 & - & - & - & - & - \\
\hline S. aureus & - & - & 1 & 1 & - & - & - \\
\hline Methicillin resistant $S$. aureus & 1 & - & - & 1 & - & - & - \\
\hline S. epidermidis & - & 1 & 1 & - & 1 & - & - \\
\hline S. pneumoniae & - & - & - & - & - & - & 1 \\
\hline Alternaria alternata & 1 & - & - & - & - & - & - \\
\hline Paecilomyces lilacinus & - & 1 & - & - & - & - & - \\
\hline Fusarium dimerum & 1 & - & - & - & - & - & - \\
\hline Acanthamoeba & - & 2 & - & - & - & - & - \\
\hline Negative culture & 3 & 1 & 2 & - & - & - & - \\
\hline
\end{tabular}

Based on the results of microbiological cultures and PCR, 15 patients were diagnosed with bacterial keratitis; three patients, with fungal keratitis; and two patients, with parasitic keratitis. Five patients presented negative microbiological tests, even though they exhibited a positive response to empirical antibiotic treatment. The most frequently isolated microorganism was Moraxella lacunata (seven cases). Microbiological test results and clinical findings are summarized in Tables 1 and 2, respectively.

The risk factors in this series were a history of ocular trauma, contact lens wear, prior ocular surgery, chronic ocular surface disease (such as keratoconjunctivitis or blepharitis) and topical corticosteroid use.

The most commonly identified risk factor was prior ocular trauma (11 patients), followed by contact lens wear (seven patients). Three patients presented systemic diseases, namely one patient with diabetes mellitus (DM) and hypertension, one with DM and one with hypothyroidism.

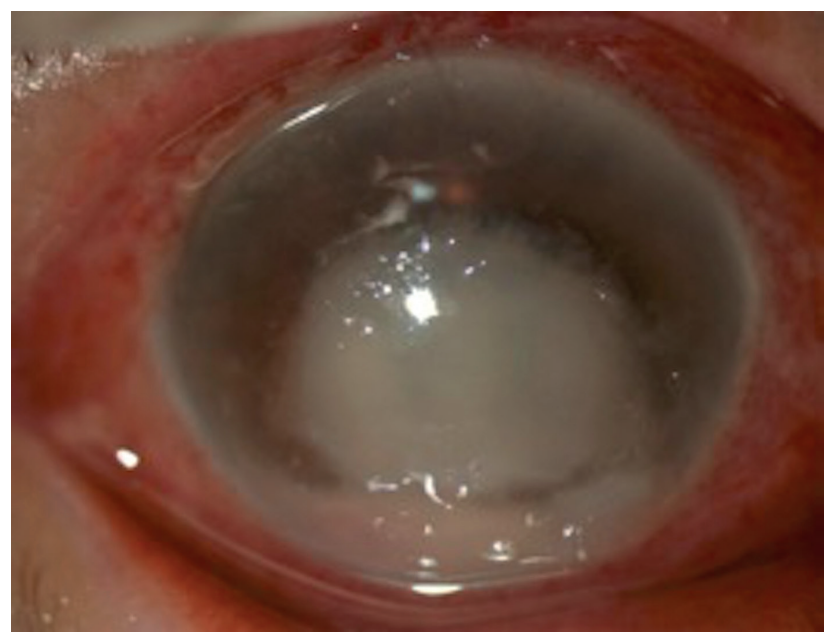

Figure 1 - Slit-lamp biomicroscopy six days after corneal trauma. An inferior corneal ulcer with an associated inflammatory infiltrate, a central abscess, bullous keratopathy and hypopyon are evident.
Table 3 summarizes the relationship between risk factors and pathogens involved.

Ocular trauma was the only risk factor identified in Alternaria alternata and Fusarium dimerum keratitis (Fig.1). The second most predominant risk factor was contact lens wear and it was the only predisposing feature in Pseudomonas aeruginosa, Paecilomyces lilacinus and Acanthamoeba keratitis (Fig. 2).

After grading the AS-OCT images, nine distinct patterns were described, as seen in Fig. 3 and Table 1.

We considered a change in convexity of the posterior corneal surface or increased corneal thickness to be signs

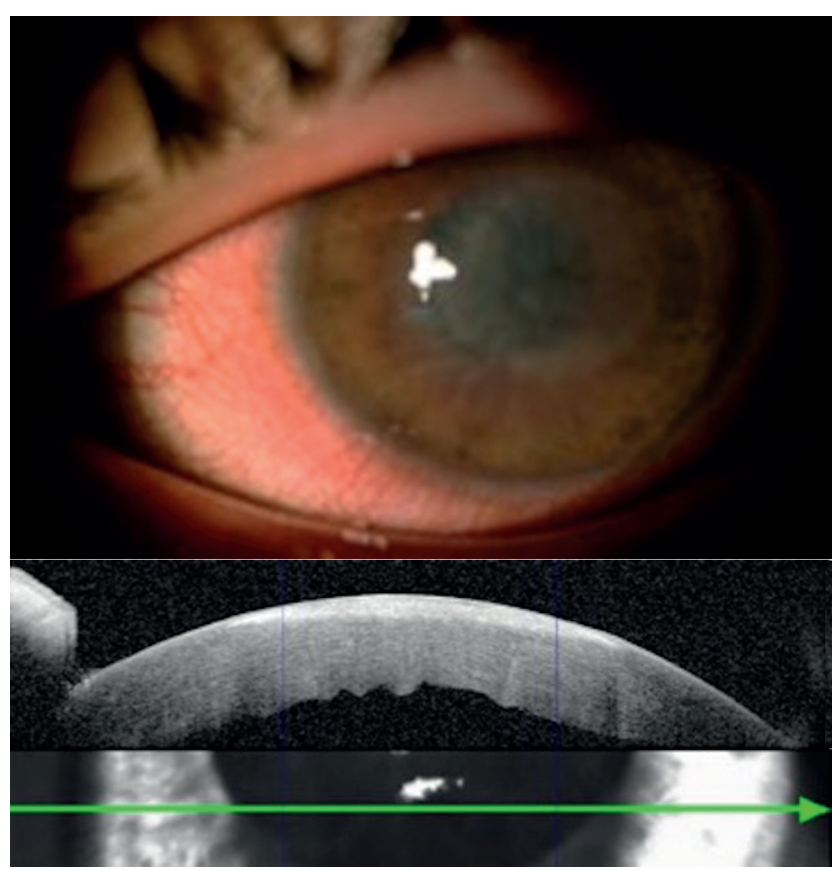

Figure 2 - Acanthamoeba keratitis. (A) Slit-lamp biomicroscopy showing an annular stromal infiltrate; (B) AS-OCT of the patient in (A) demonstrating a hyperreflective stromal lesion and stromal edema. 

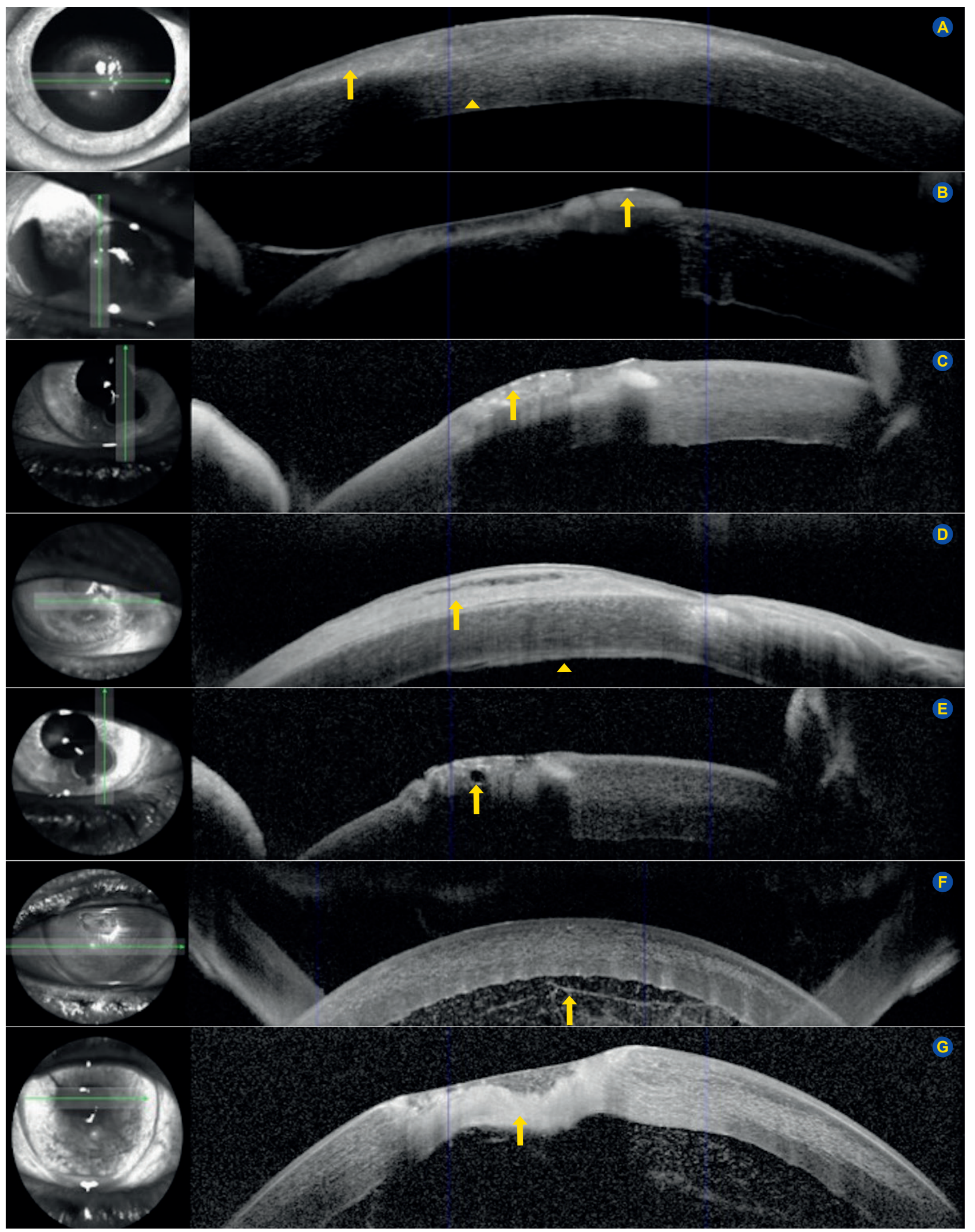

Figure 3 - Different anterior segment optical coherence tomography patterns in infectious keratitis. (A) Hyperreflective stromal lesion (arrow); Stromal edema (arrowhead); (B) Epithelial and stromal hyperreflective punctate lesions (arrow); (C) Hyperreflective material over lost epithelium or over hyperreflective stromal lesion (arrow); (D) Hyperreflective material over intact epithelium (arrow), Hyperreflective lesion attached to the corneal endothelium (arrowhead); (E) Cystic spaces (arrow); (F) Membrane shape hyperreflective lesion in anterior chamber (arrow); (G) Stromal thinning (arrow). 


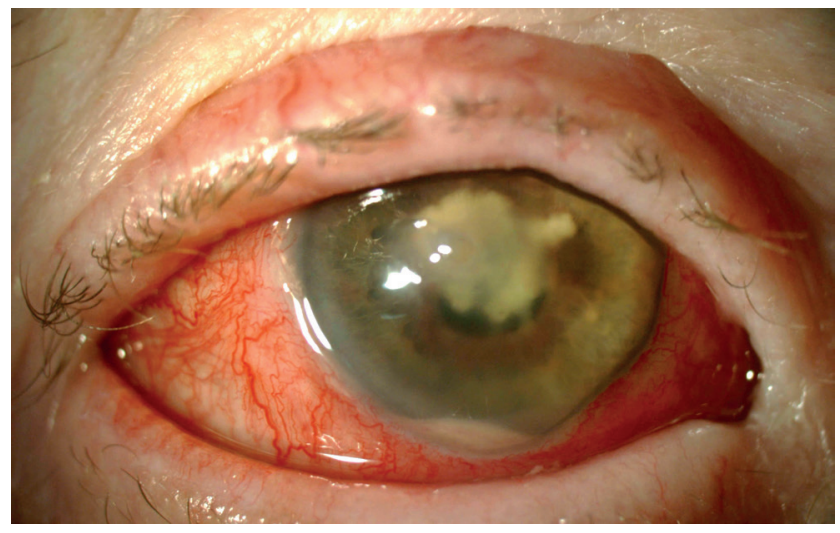

Figure 4 - Citrobacter braakii keratitis. Slit-lamp biomicroscopy showing temporal paracentral corneal thinning, hypopyon, an inflammatory membrane in the pupillary area (corresponding to Fig. 3F) and iris bombe.

of stromal edema.

Eyes with full thickness corneal involvement or with the presence of stromal cysts presented more severe clinical findings, as exemplified in Fig. 4 that shows the biomicroscopy of a patient with Citrobacter braakii keratitis. After resolution of the acute infection, the patient had a best corrected visual acuity of 20/200.

\section{DISCUSSION}

As in previous studies, the most frequently identified risk factors were ocular trauma and contact lens wear. ${ }^{2,3,15}$ Risk factors were absent in only two cases. The known association between the use of contact lenses and infectious keratitis caused by $P$. aeruginosa or Acanthamoeba was corroborated by our study. ${ }^{15-17}$

Nine of the patterns described by Soliman et al ${ }^{14}$ were coincident with ours. We also interpreted a hyperreflective stromal lesion as a stromal infiltrate and hyperreflective material over lost epithelium or over a hyperreflective stromal lesion as an inflammatory plaque or mucus. Corneal infiltrate and edema have been largely reported in histopathological studies of infectious keratitis. ${ }^{18}$ In fact, these patterns were observed in almost all patients in the initial stages, and even mild cases have a thickened cornea in the infiltrated area. When isolated, these patterns may reflect a lower grade of keratitis severity, since we observed that five out of six patients presenting only a hyperreflective stromal lesion with stromal edema had better final visual outcomes, with a best final corrected visual acuity of 10/10 (Snellen scale). The infiltrated area can be measured on high-resolution corneal scans. Additionally, corneal thinning may be detected earlier in AS OCT than in clinical examination. ${ }^{13}$ Indeed, one of the patterns identified was stromal thinning, which was associated with corneal melting observed in slit-lamp examination of severe cases of IK ( $P$. lilacinus, $P$. aeruginosa, $S$. epidermidis, $S$. pneumoniae and Citrobacter braakii). Serial AS-OCT examinations can be used to monitor in vivo the clinical course of infectious and inflammatory diseases, by measuring both corneal thickness and the size of hyperreflective lesions. ${ }^{19}$
Cystic spaces may represent localized stromal necrosis. Contrary to Soliman's ${ }^{14}$ study, our results showed that cystic spaces were not exclusive to fungal keratitis. Indeed, they were present in keratitis with a more aggressive course, namely $C$. braakii keratitis, which is, to our knowledge, the first time that this has been described. Besides cystic spaces, C. braakii keratitis was evidenced by a hyperreflective lesion in the anterior chamber, compatible with an inflammatory membrane, which in turn is associated with a hyperreflective stromal lesion and corneal thinning, suggesting a severe inflammatory reaction in the anterior chamber and poor prognosis.

We interpreted hyperreflective material attached to the corneal endothelium as an inflammatory plaque. Vemuganti et $a^{20}$ demonstrated that the progression phase of fungal keratitis is characterized by the spreading of fungal abscesses into the anterior chamber with a fragmented Descemet's membrane. Retrocorneal plaques are found not only in fungal keratitis but also in bacterial and viral keratitis. Indeed, in our study, this type of lesion was present in fungal and gram positive or negative bacterial IK. Takezawa et $a^{21}$ analyzed retrocorneal plaques using AS-OCT and concluded that they may be a clinical indicator of the severity of keratitis. AS-OCT showed that the boundary between the cornea and plaque was clear in patients with bacterial IK that responded to medical therapy. On the other hand, all patients with an unclear endothelial surface required surgical intervention and this feature was more common in fungal keratitis. In our study, two out of three cases of fungal keratitis presented this pattern. The particular case of keratitis by Fusarium dimerum (Fusarium penzigii) has been published recently, with the reporting of pan-corneal involvement. ${ }^{22}$

Both cases of Acanthamoeba keratitis presented identical morphological features (superficial hyperreflective stromal lesions associated with stromal edema), which suggests an early stage of infection. Recent reports have described the visualization of Acanthamoeba cysts in the basal epithelial cell layer as highly reflective round particles, and radial keratoneuritis as highly reflective bands or lines of various widths. ${ }^{23}$ Although we did not identify clear hyperreflective clusters, the stromal hyperreflectivity was more intense in the subepithelial area, which can be related to the presence of Acanthamoeba cysts.

Tu et $a^{24}$ demonstrated that a deep stromal involvement was an independent predictor of severity in IK caused by Acanthamoeba. AS-OCT allows the involvement in the different corneal layers to be determined, helping in estimating the severity and prognosis.

Hyperreflective material over intact epithelium was only present in one case of keratitis, caused by methicillin resistant Staphylococcus aureus (MRSA). In this case, we also observed stromal and endothelial involvement, stromal edema and hyperreflective material attached to the endothelium. These pan-corneal lesions in MRSA cases might be related to the role of alpha exotoxin, the main culprit in the pathophysiology of this type of keratitis. Alphatoxin 
targets several types of cells, forming pores that cause osmotic lysis and cell death. ${ }^{25}$

Nowadays, the ultrahigh-resolution spectral domain OCT system based on a broad bandwidth Ti:sapphire laser allows OCT data of the entire corneal surface to be obtained with $1.2 \mu \mathrm{m} \times 20 \mu \mathrm{m}$ (axial $\mathrm{x}$ lateral) resolution at a rate of $140000 \mathrm{~A}$-scans/s. Using this type of technology, structures of the anterior segment of the eye that are not accessible using commercial OCT systems can be visualized, namely corneal nerves and limbal palisades of Vogt, as well as several corneal disorders. ${ }^{26}$ Therefore, in the future, AS-OCT may be an even more valuable device in the management of IK.

Our study suffers from the limitations inherent in a crosssectional design, as we cannot make inferences regarding the temporal sequence of corneal lesions. However, our goal is to help in the early diagnosis of corneal infections and so it was important to perform the AS-OCT in the initial visit.

One limitation of this study is that the sample size is too small to detect any effect in a statistical analysis. Despite the small sample size, to the best of our knowledge, this is the largest study describing AS-OCT patterns in infectious keratitis.

Although the determination of the causative agent by identifying these patterns is still limited, this study presents important novel findings that pave the way for further research in the early identification of corneal infections. ASOCT should be considered a useful test in the presentation of a patient with $\mathrm{IK}$, allowing for a more precise follow up and prediction of prognosis.

\section{CONCLUSION}

AS-OCT allows the depth of corneal involvement in IK to be assessed and patterns that can aid in the staging and prognosis of the disease to be characterized.

Indeed, our findings suggest that localized necrotic stromal cystic spaces are not exclusive to fungal keratitis, contrary to what was previously believed. Instead, it is characteristic of severe bacterial or fungal keratitis at an advanced stage. In addition, we show that the isolated presence of hyperreflective stromal lesions and edema points to a more favorable course of the disease. In contrast, pan-corneal involvement is associated with more aggressive agents, such as MRSA, that reach the anterior chamber through the production of $\alpha$-toxin exoproteins.

\section{OBSERVATIONS}

Presented at $8^{\text {th }}$ EuCornea Congress, October 6- $7^{\text {th }}$, 2017, Lisbon, Portugal.

\section{PROTECTION OF HUMANS AND ANIMALS}

The authors declare that the procedures were followed according to the regulations established by the Clinical Research and Ethics Committee and to the Helsinki Declaration of the World Medical Association.

\section{DATA CONFIDENTIALITY}

The authors declare having followed the protocols in use at their working center regarding patients' data publication.

\section{CONFLICTS OF INTEREST}

All authors report no conflict of interest.

\section{FUNDING SOURCES}

This research received no specific grant from any funding agency in the public, commercial, or not-for-profit sectors.

10. Izatt JA, Hee MR, Swanson EA, Lin CP, Huang D, Schuman JS, et al. Micrometer-scale resolution imaging of the anterior eye in vivo with optical coherence tomography. Arch Ophthalmol. 1994;112;1584-9.

11. Ramos JL, Li Y, Huang D. Clinical and research applications of anterior segment optical coherence tomography - a review. Clin Exp Ophthalmol. 2009;37:81-9

12. Lim SH. Clinical applications of anterior segment optical coherence tomography. J Ophthalmol. 2015;1-12.

13. Konstantopoulos A, Kuo J, Anderson D, Hossain P. Assessment of the use of anterior segment optical coherence tomography in microbial keratitis. Am J Ophthalmol. 2008;146:534-42.

14. Soliman W, Fathalla AM, El-Sebaity DM, Al-Hussaini AK. Spectral domain anterior segment optical coherence tomography in microbial keratitis. Graefes Arch Clin Exp Ophthalmol. 2013;251:549-53.

15. Ng AL, To KK, Choi CC, Yuen LH, Yim SM, Chan KS, et al. Predisposing factors, microbial characteristics, and clinical outcome of microbial keratitis in a tertiary centre in Hong Kong: a 10-year experience. J Ophthalmol. 2015;2015:769436.

16. Vazirani J, Wurity $\mathrm{S}$, Ali $\mathrm{MH}$. Multidrug-resistant pseudomonas aeruginosa keratitis: risk factors, clinical characteristics, and outcomes. Ophthalmology. 2015;122:2110-4.

17. Mascarenhas J, Lalitha P, Prajna NV, Srinivasan M, Das M, D'Silva SS et al. Acanthamoeba, fungal, and bacterial keratitis: a comparison of risk factors and clinical features. Am J Ophthalmol. 2014;157:1-20.

18. Messmer E. Keratitis - infektiösoderautoimmun? Klin Monbl 
Augenheilkd. 2016;233:808-12.

19. Konstantopoulos A, Yadegarfar G, Fievez M, Anderson DF, Hossain P. In vivo quantification of bacterial keratitis with optical coherence tomography. Invest Ophthalmol Vis Sci. 2011;52:1093-7.

20. Vemuganti GK, Garg P, Gopinathan U, Naduvilath TJ, John RK, Buddi $\mathrm{R}$, et al. Evaluation of agent and host factors in progression of mycotic keratitis: A histologic and microbiologic study of 167 corneal buttons. Ophthalmology. 2002;109:1538-46.

21. Takezawa Y, Suzuki T, Shiraishi A. Observation of retrocorneal plaques in patients with infectious keratitis using anterior segment optical coherence tomography. Cornea. 2017;36:1237-42.

22. do Carmo A, Costa E, Marques M, Quadrado MJ, Tomé R. Fusariumdimerum species complex (fusariumpenzigii) keratitis after corneal trauma. Mycopathologia. 2016;181:879-84.
23. Yamazaki N, Kobayashi A, Yokogawa $H$, Ishibashi $\mathrm{Y}$, Oikawa $\mathrm{Y}$, Tokoro $\mathrm{M}$, et al. In vivo imaging of radial keratoneuritis in patients with Acanthamoeba keratitis by anterior-segment optical coherence tomography. Ophthalmology. 2014;121:2153-8.

24. Tu EY, Joslin CE, Sugar J, Shoff ME, Booton GC. Prognostic factors affecting visual outcome in Acanthamoeba keratitis. Ophthalmology. 2008;115:1998-2003.

25. O'Callaghan RJ, Callegan MC, Moreau JM, Green LC, Foster TJ, Hartford OM, et al. Specific roles of alpha-toxin and beta-toxin during Staphylococcus aureus corneal infection. Infect Immun. 1997;65:15718.

26. Werkmeister RM, Sapeta S, Schmidl D, Garhöfer G, Schmidinger G, Aranha Dos Santos V, et al. Ultrahigh-resolution OCT imaging of the human cornea. Biomed Opt Express. 2017;8:1221-39. 